\title{
Critical Views on Implementing English Language Teaching Curriculum with Native \& Non-Native English Language Teachers
}

\author{
Md. Jahangir Alam \\ English Language Center \\ Faculty of Languages \& Translation, \\ King Khalid University \\ Abha, Saudi Arabia
}

\begin{abstract}
Despite the non-native English-speaking professionals' movement which has started more than twenty years ago; native and non-native dichotomy is still considered to be the major paradigm for exploring English language teachers' identity development. According to the researchers however, this act of categorizing people based on their language orientation is symbolic and used to produce discursive unity within a greater diverse group (Blackledge \& Pavlenko, 2001). And we need to inspire and promote users' appropriation of English so that, speakers of English may take ownership of the language (Phan, 2009). ELT curriculum which is the tip of the ice-burg of this immense phenomenon, reflects stake-holders' perception about native or nonnative teachers. Drawing on literature from the field of English language teaching and theories of sociology this article attempts to present a contextual understanding of this crucial debate and goes further to suggest some steps.
\end{abstract}

Keywords: English language curriculum; native; non-native teachers.

\section{Introduction}

English Language Teaching (ELT) classroom can be considered to be the melting pot of ideas related to culture, language and identity. It is an obvious site of struggle for recognition and legitimation. Peeping through an ELT classroom one can get a glimpse of the process where identities are being constructed; cultural understandings are being formulated. ELT teachers'(identity) who are at the heart of this critical site has always been the subject of scrutiny. Traditionally however, native speakers were considered to be the only reliable source of linguistic data for many years (Chomsky, 1965). Davies (1991) examined the 'native speaker' identity and posed a fundamental question: whether a second language learner can become a native speaker of the target language. He concluded, second language learners can master the intuition and pragmatic 
control of the target language like the native speakers. Robert Phillipson (1992) further delved into NS (Native speaker) identity and coined the term "native speaker fallacy'- the commonly accepted belief that natives are the ideal teachers of language. While the authority was acknowledged there appeared a power struggle between NS and Non-native English speaking teachers (NNEST). The dissatisfaction is properly captured in the following comment: we

\begin{abstract}
"make sense of the world to a large extent on the basis of personal experiences and cultural beliefs that arise out of collective histories...It is always worth asking why, and from whose point of view, one way of using language seems obvious, natural and neutral, while another seems ludicrous, loaded and perverse" (Deborah Cameron, 2005:159).
\end{abstract}

English language teaching curriculum is the medium through which stakeholders validate their perception about native or non-native teachers as observed by Higgins (2003): This act of labelling language teachers or students as native or non-native is much of what English language teaching professionals do. Moreover, NNEST label itself constructs an identity indicated by being different than the standard along the racialized line (Norton \& De Costa: 2019).

\title{
2. English Language Teaching Context: Saudi Arabia
}

Saudi Arabia, founded (unified) by King Abdul Aziz in 1932. With the land mass of approximately 830, 000 square miles it is the largest Arab country in the Arabian Peninsula. The country is surrounded by other Arab countries like: Yemen, Bahrain, UAE, Qatar, Syria, Jordan, and Egypt. Saudis are 98\% Muslim and speak Arabic as their mother tongue (Al-Seghayer, 2005). Strong tribal and religious bondage make Saudis a unique nation in the world. The country hosts $33 \%$ expatriates of its total population (Arab news, 2015). A nation bound by strict religious and cultural belief systems, opened to the outside world with its newly-found identity as the world's major petroleum exporter.

Saudi Arabia was never colonized by any European nation except Turkey. So, the first foreign language (FL) ever taught in Saudi Arabia was Turkish, that too did not receive widespread acceptance because they regarded Turkish as the language of oppressors (Al Ghamdi, cited in Mahboob \& Elyas, 2014). With the rapid economic development, this attitude towards foreign language changed and a need to train local students to go abroad and receive western education was identified. To meet this demand, Scholarship Preparation School was established in 1936 in Makkah. For several decades (1970-2001) English was taught to Saudi students at grade 7 at the age of 13-14. Students studied English six years until grade 12 at secondary level (Mahboob \& Elyas, 2014). In 2003, Saudi Government decided to introduce English in all primary schools with reformed ELT curriculum. Ever since, English language has gained popularity. Every year hundreds of university graduates (male and female) are going abroad with Scholarship Program to complete their post-graduation courses.

Considering the global trend of English expansion pattern, its acquisition, and functionality, Saudi Arabia falls in the expanding circle (Kachru, 1992) as English is taught here as foreign language (FL). The other two among Kachru's concentric circles are: inner circle and outer circle. Expanding circle however, 
expanding rapidly and generated several performance-based varieties of English. Kachru's model (1992) faced various criticism as Park \& Wee (2011) observed: it 'has the unintended consequences of justifying and reproducing the hegemony of Inner Circle speakers and their Englishes' (p. 392). Nevertheless, it can be instrumental as a reference point as to where does countries like Saudi Arabia stand in the arena of Global-English expansion. As many other expanding circle countries the available English language variety in Saudi Arabia is mainly performance based. The non-native (local) English teachers receive training in the inner circle countries and teach either American or British English in the classroom (Al-Asmari \& Khan, 2014). To address the growing demand of teachers, Saudi Ministry of Higher Education regulate and adopt a policy to recruit foreign English language teachers from various nationalities. A general categorization of the teachers recruited to teach local Saudi students is as the following:

Table 1: ELT teachers' category (Saudi Universities) source: KKU Website

\begin{tabular}{|l|l|l|l|l|}
\hline N & Nationality & Country & Category & L1 \\
\hline 1 & Arab (Local) & Saudi & NNESTs & Arabic \\
\hline 2 & Arab (other Arab countries) & $\begin{array}{l}\text { Sudan, Egypt, Syria } \\
\text { etc. }\end{array}$ & NNESTs & Arabic \\
\hline 3 & $\begin{array}{l}\text { Non-Arab (Asian or } \\
\text { European) }\end{array}$ & $\begin{array}{l}\text { Romania, India, } \\
\text { Pakistan, Bangladesh }\end{array}$ & NNESTs & $\begin{array}{l}\text { Romanian, } \\
\text { Hindi, Urdu } \\
\text { or Bengali }\end{array}$ \\
\hline 4 & $\begin{array}{l}\text { Native English Speaking } \\
\text { Teachers }\end{array}$ & $\begin{array}{l}\text { Central Countries: } \\
\text { America, Canada, U. K } \\
\text { \& Australia }\end{array}$ & NESTs & English \\
\hline 5 & $\begin{array}{l}\text { Native English Speaking } \\
\text { Teachers (peripheral) }\end{array}$ & South Africa & NESTs & $\begin{array}{l}\text { English (Local } \\
\text { variety) }\end{array}$ \\
\hline
\end{tabular}

Among the ELT teachers, there are mixed groups of non-native English language teachers whose L1 is Arabic (but they are not Saudi). This group constitutes the majority of the teachers. These non-native other Arabs share the common language although they may be culturally very different. Among other non-native, there are teachers who come from the Asian and European countries like: Pakistan, India, Bangladesh and Romania. Teachers of this category have least or no knowledge of Arabic (Students' L1) and they are totally unaware of the local culture. The native English language teachers (from central countries) mainly come from United States and United Kingdom.

\section{ELT Curriculum in Saudi Schools \& Universities}

Although, Saudi Arabia had never been colonized by any European power except Turkey (Ottoman Empire: Turkish language) it has always been the hub of one international religious gathering: the yearly Muslim congregation (Hajj). Nearly two million Muslims from all over the world come to Mecca to perform this ritual every year. The medium of communication during Hajj is either Arabic or Urdu, sometimes English. Shortly after the establishment of the Kingdom, the government of Saudi Arabia realized the importance of training 
its citizens in English to better communicate with the outside world. This effort was only intensified with the discovery of petroleum. The Arabian American Oil Company (ARAMCO) established in 1968, played an important role in Saudis economic growth and its outward look; necessitating English as a medium of communication. At the early stage of oil production, there was a huge demand of Saudis who could communicate with foreigners especially with American experts. It is commonly believed that, 'because English is a dominant world language, access to English provides students with 'linguistic capital' (Hilary Janks, 2004) and linguistic market has important consequences for the teaching of a powerful language such as English (Bourdieu, 1991). Nevertheless, there was no definite ELT curriculum for several decades at the beginning of the last century. The early 1960s witnessed the development of a first ever comprehensive EFL curriculum: Living English for the Arab. This was mainly adapted from the neighbouring country's (mostly Egypt) curricula and it remained the corner stone of ELT curriculum until 1980s (Allen \& Cooke cited in Al- Seghayer, 2005). Before the end of the last century two more EL (English Language) programs in the name: Saudi Arabian Schools English (1980) and English for Saudi Arabia (1991) were included in EFL curriculum. Saudi universities which come under Ministry of Higher Education formulate their own individual curriculum for the English Language preparatory courses of various graduate programs.

\section{English Language Teaching (ELT) Approaches in Curriculum}

Curriculum is the reflection of the context in which that curriculum is situated (Graves, 2008). As mentioned earlier, the context of Saudi Arabia is characterized by strict social and religious values: education up to the university level is segregated into men and women and since English is not immediately relevant to students' need, most of them do not pay serious attention to language learning (Al-Seghayer, 2005). So, one widespread understanding among the teachers that, students lack in motivation. An inevitable outcome of this situation was: teachers resort to Audio-lingual method (ALM) mixed with Grammar Translation Method (GTM). Rote memorization and grammar-drills were the approach implemented in the classroom. Zaid (1993) observed that, Audio-Lingual Method without the use of language laboratory was the most popular method in ELT classroom. So, the growing complain was: 'students are not exposed to authentic spoken English' (Al- Seghayer, 2005:129). Later, the debate over 'Authentic English' will be associated with NESTs (Native English Speaking Teachers) or to make it more obvious Native American or British teachers.

At the university education, prospective students enroll in an intensive English language program for one or two semesters. Upon completion, they join their respective graduate programs. To meet the demand of fluency over accuracy and to face students' lack of intrinsic motivation, ELT professionals introduced Communicative Language Teaching (CLT) for Intensive English Language courses. Needless to say, CLT was being implemented by the teachers coming from various backgrounds (native or non-native/Arab or Asian). Ministry of Higher Education in partnership with various British-American publishing 
houses introduced local version (edited) series like: Headway, Tapestry or Touchstone. But, Canagarajah (1999b) argues, learning process varies according to cultural context, therefore, what might be appropriate in one culture may be completely a failure in another. These books however mainly follow conversational strategy of communicative language teaching and seem to ignore the local context. About which Bax (2003) rightly pointed out:

"CLT discourse constantly sends out the message to teachers and educators that the priority is for the teacher to generate communicationwhile the context is not mentioned" (p. 281).

One Example of CLT being implemented out of context is, ideas like: snorkeling, bargains on the internet and places like Puerto Rico, San Juan may sound too out of context for the students potentially generating lack of interest in the teaching content. Phan Le Ha (2009) critiques and terms CLT as irrelevant where the context is not Western. A learner centered approach like CLT requires contextual-binding of the teaching materials and teachers need to be aware of the context and students' interest to motivate them in conversation. Lack of motivation in the teaching material and teacher can result in failure. As observed by Wajid \& Saleem (2016): In Saudi Arabia

"Learners being tradition bound, culturally and mentally, to the established norms that a teaching approach like CLT might look to them to be counterproductive and thus a waste of time and energy" (p.48).

\section{NESTs (Native English Speaking Teachers') Position in CLT}

It is widely believed that, learners tend to associate native speakers with pronunciation, language skills, and target language cultural knowledge and non-native speakers with grammatical accuracy (Lasagabaster \& Sierra, 2002). Being an expanding circle country where English is a foreign language, students do not find atmosphere where they can practice English language. Lack of authentic language learning situation outside the classroom makes learning even more challenging for the students (Alharbi, 2015). This demand for authentic conversation in the classroom and an emphasis on fluency over accuracy led the educational institutes around the world recruit more and more native English language speakers. Now-a-days, this demand for Native English Speaking Teachers (NESTs) is so high that, in some cases, the only qualification required is the native speaker identity. Teacher training courses are considered to be added qualification to teach English language.

This process of over lenience towards the native speakers have led the researchers question the very essence of CLT and native speakers construct. First, the dilemma about the NESTs is, how to define the term native speaker? Canagarajah (1999a) questions this whole concept of native speaker and argues that, in the post-colonial era there are different varieties of English exist in different parts of the world and speakers of those languages can claim to be native speakers. From the linguistics' perspective the concept remained even more vague. Chomsky's (1965) view: of native speaker is the ideal speaker or 
listener of a speech community later believed to have laid the foundation Native Speaker discourse. However, this phenomenon is more to the side of identity construct than to language teaching. As researchers pointed out: the construct of nativeness itself is

"a non-elective socially constructed identity rather than a linguistic category" (Brutt-Griffler \& Samimy cited in Butler, 2007:100).

\section{Advantages and Challenges of Being a Native Speaking Teacher}

Native speakers of a language can facilitate a learning process by projecting himself as the role model of target language for the students. NS (Native Speaker) is supposed to have full knowledge about the target language culture, he/ she can help students identify themselves in the L2 culture. Motivation to acquire the target language and its features depends on availability of identification with the L2 culture (Pienemann, 1985). Absence of NS means less chance of social identification on the part of the students. As it was observed by Schumann, (1986): acquisition of the second language depends on the degree to which the learner acculturates himself with the target language culture. As a member of the same speech community NS is aware of the extra linguistic features of the language. So, he/she can be present in the class with all the available L2 linguistic features like accent, idiomatic expressions etc. However, the prime challenge that NS faces is lack of knowledge about students' culture so to say contextual understanding. NS will feel and project himself as alien unless he has knowledge about the local culture of the students. Sometimes, it is difficult for the NS to reach up to each and every individual student to help them with scaffolding simply because he/she does not know the students' L1. Another issue about NS is: they stay for short term and then leave; which does not yield any long term benefit for the students. As Kirkpatrick (2007) points out: Since NESTs stay for a short term they bring very little long term benefit. On the flipside, this myth of native-speakerism also degrades NS teachers to some extent as they are often treated as commodity to serve an industry which is hungry of NS ideal (Holliday A., 2015).

The discussion of Native and Non-native teacher takes even more complicated turn when it is considered as a socio-cultural aspect. Question arises whether students or other non-natives are being treated as object put into the process of identity formation; which they would not have been into if given a choice (!). This argument grows stronger when we look into our colonial history (how this concept first came into being). The seed of allegiance towards the greater power lying hidden in our history. In Macaulay's Minute on Indian education (1835) it had been interestingly pointed out: British colonial power wanted to establish an elite class of Native Indians who will be distinguishable by their English language and culture. One point of his minute mentions:

"I feel with them, that it is impossible for us, with our limited means, to attempt to educate the body of the people. We must at present do our best to form a class who may be interpreters between us and the millions whom we govern; a class of persons, Indian in blood and color, but English in taste, in opinions, in morals, and in intellect" (Point-34). 
However, this is the very nature of learning and teaching of L2, it can never be as simple as conveying and receiving linguistic codes or rules but, becoming somebody else in process (Prior, 2001). According to Spolsky (1969): learning a language requires the learners to shift their allegiance to the target language community. As it is mentioned before, Saudi Arabia was never a British colony yet, it is under significant cultural and economic hegemony of its American counterpart (a neo-colonial aspect with almost the same demanding characteristics).

\section{Linguistic Exchange or Language Teaching (LT) as 'Socio-Cultural Capital'}

The binary relationship between native and non-native teachers is aligned with standard and non-standard variety of language. Researchers (like Bourdieu) have focused on the materialistic aspect of language teaching. According to Bourdieu (1991:395): 'Varieties that are indexically linked with powerful speakers come to be valued more highly than others... symbolic power accorded to them are transferred onto their utterances, transforming them into valued symbolic capital'. This feature of language teaching is evident in the ESP (English for Specific Purposes) programs, where capitalist market demands employee with specific standard of linguistic competence. Language testing programs like: IELTS or TOEFL are just two examples where symbolic value is attached with scores or grades. These standard tests present the test-takers with American, British or Austrian variety of English giving the impression of limited recognized varieties. Bourdieu's (1991) equation is as simple as this:

\section{"Language $=$ Social and Cultural capital"}

The question of language variety falls under the discourse of linguistic superiority. This is apparent that, certain linguistic practices construct the dominant speaking discourse. Subsequently, that language pattern come to be recognized as having materialistic aspects (Roberts \& Sarangi, 1995).

\section{NESTs Construct \& Circuit of Culture}

Stuart Hall (1997) termed language as the privileged medium through which shared meaning is constructed and the whole process is accomplished through a representational practices channelled through Circuit of Culture. If we consider 'Native English Speaking Teacher' as a construct which associate some values and understanding then, like any other representational component it also seemed to have passed through various stages of the sequence of culture. There's an interplay of similarity and difference in language that is 'a group marker, an indicator of difference and ultimately both the medium and the message of the construction of 'us' as opposed to 'them' (Wright, 1997:216). 


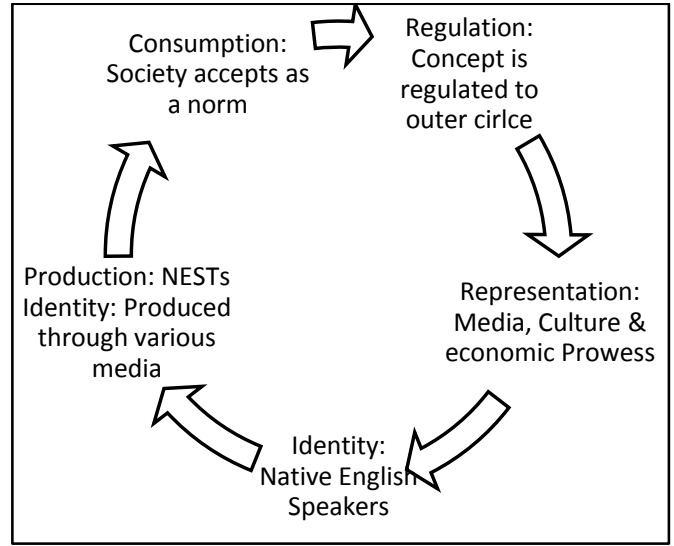

Figure 1: Native English Conceptualization through Circuit of Culture.
Language mark someone as different with the extra linguistic features like accents. Specific language pattern makes inner circle of native speakers hence, mark out the non-native. As fundamental to the constitution of ourselves is the need to mark others as different (Hall, 1997). The native speaker-superiority then cycled through the various representational practices like: popular culture and media. Henceforth, the emergence of RP (Received Pronunciation) and GA (General American). According to Miller (2003) if you sounded the same, you were not 'seen' as 'different'. Therefore, different audible accent represents difference among its speakers. The objective of target language like competence (nativespeaker-like) is not communicative, rather social identification (Nicholas, 1985).

\section{Positioning Non-NESTs in the EFL Curriculum}

At the end of colonial power ('British Raj' for example in India), there was this demand that Native Languages will replace English from the colonized nations. The demand was not for identification with English rather for abolition of English (Kachru, 1992). Newly independent countries went through this process of 'Identity' formation detaching themselves from their earlier identity. At the later part of $20^{\text {th }}$ century that endeavour seemed to have taken over by the efforts for standardizing Non-Native local varieties of English. This process of regulating local variety is continuous and yet not achieved. Meanwhile, the native-speaker teacher construct is criticized by many researchers. Phillipson (1992) termed it as fallacy or myth. However, many non-native teachers seem to hold the stereotype against themselves and perceive themselves as inferior to their counterparts. As this process is institutionalized, NNESTs are still viewed as teachers in need of assistance from the native speakers as the former consider the later as reference point for language proficiency (Phan, 2008). In this prevailing situation NNESTs can easily identify themselves with Eva Hoffman's (1989) experience as an immigrant L2 learner:

"Since I lack a voice of my own (in English), the voices of others invade me ... They ricochet within me, carrying on conversations, lending me their modulations, intonations, rhythms. I do not yet possess them; they possess me... Eventually the voices enter me; by assuming them, I gradually make them mine" (p. 219).

\section{Non-Native Interlanguages}

In the question of non-native's endeavor to acquire native like accent, Medgyes (1992) believe that non-native will never be able to attain the native competence 
in the target language. Non-native speakers' competence is limited and only a limited group can attain native or near native competence. Moreover, some of these L2 learners may have become fossilized. So, it's not ideal for everybody to thrive for native competence. A more liberal approach of L2 learning is, all users of English are simultaneously placed in a continuum of language learning. And they can be placed in the Interlanguage continuum according to their command in target language (Selinker cited in Medgyes, 1992). Following is the Selinker's (1972) model of Interlanguage continuum:

Inter language continuum

Zero Competence $(0 \%)===$ Near Native Competence $(90=95 \%)===-$ Native

Figure: 2 Interlanguage Continuum (Source: García Merino, 1997)

Interlanguage is the type of language variety where grammar rules are simplified to serve communicative purposes, it is communicative but may not be standard. It is wrong to consider interlanguage as incorrect rather it is the most perceivable outcome of language learning process. In EFL situation like Saudi Arabia interlanguage is common and teachers need to establish this norm that, everybody is the L2 learners in Interlanguage continuum. Teachers (native or non-native) are only the advance learners.

\section{Advantages of Non-Native English Speaking Teachers}

According to Medgyes (1999) NNESTs may have such shortcomings as linguistic deficiency and "inferiority complex" but because they position themselves "at a junction between two languages and several cultures" (p. 36-37) they have certain advantages which the native speakers lack. NNESTs can project themselves as the achievable model of L2 learning. Thus, they can establish trust among the students. Second, NNESTs will speak in tone and accent (interlanguage) that is easily understandable for the students. Students do not have to gasp in keeping pace with the native accent and fluency. Native accent can be counterproductive for the NESTs, because accent sometimes works as marker of difference. Student will not be able to identify themselves with the native English teachers. Miller (2003): accent can be considered as audible difference which pronounces racial taxonomies and which has proximity to whiteness. In implementing CLT Stephen Bax (2003) suggested, the consideration of context should come first then should come teaching approach. And who has better contextual knowledge other than the non-native local English teachers.

\section{Standard English VS World or Global Englishes}

Standard English is stated as the distinct variety of language that follows the rules of grammar and spelling presented in the textbooks and dictionaries (Trudgil \& Hannah, 2017). However, the debate of native or non-native English is the socio-cultural-political debate in question of standard variety of English. Language is a floating concept, it transforms and never remains static. An attempt to find a common ground is culture's way to bringing things in order 
(Synchronic cultural effect) and predictability into people's use of language' (Kramsch, 1998). Standard English or 'Received pronunciation' is a concept processed through culture as a norm and accepted by the majority of people. It creates an inner circle producing the controversial concept of 'others'. Hence, one of its critics said: Standard English (SE) is:

"A bias toward an abstracted, idealized, homogeneous spoken language which is imposed from above, and which takes as its model the written language" (Lippi-Green, 1994: 166).

However, English is termed as 'Global Language' since it is the official language in some countries and in some others is the priority foreign language.

"language achieves a genuinely global status when it develops a special role that is recognized in every country" (Crystal cited in Nunan, 2003).

This global recognition comes with the cost of innumerable language varieties. The inevitable consequence of these varieties is, they challenge the notion of 'native speaker' and ideologies of what 'proper English' sounds like (Eslami, Moody \& Pashmforoosh, 2019) which prepares the ground for more varieties and eventually the emergence of World Englishes" (WE).

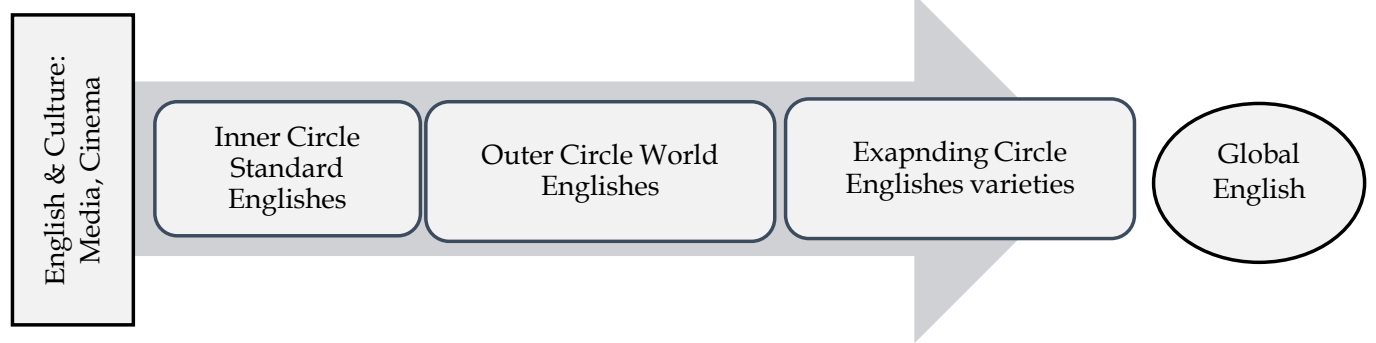

Figure 3. Global English (Adopted from PhiN 32/2005:1)

World Englishes (plural emphasis) is a term used to identify the various localized varieties of English which have been generated in contact with diverse socio-cultural phenomenon. A more recent term for this is 'Global English' to highlight the effect of globalization on English language. Due to globalization of English language, it is presumable that, the native variety of English produced in inner circle-countries will no longer remain the same. This trend of local variety of English will continue to grow in future. Teacher educator should take this matter into consideration. In EFL condition like Saudi Arabia, it is arguable whether ELT teachers should teach English as a global English. Although ELT curriculum limits scope within the Standard British or American varieties. But teachers always can make their students aware of the world Englishes so that, they can come out of the narrow objective. Students should realize,

"there as many more speakers of world Englishes.... than there are native speakers of it" (Kirkpatrick, 2007:1). 
Teachers on the other hand, should be aware of recent development in World Englishes. It should be included in teacher-training programs so that, teachers can compare and explain different varieties in the classroom. Recent inclusion of World Englishes in various TESOL programs is one step towards this direction.

\section{Recommendations}

It is obvious that there're whole lot of ideas and counter ideas revolving around the concept of Native or Non-Native English Speaking Teachers. In process, English is spreading, crossing national boundaries to unknown territories. So, we need to broaden our perspective to understand and evaluate the Global English Discourse. And, future teachers must be aware of the diverse range of English language they are about to encounter while teaching (Matsuda, 2017). Based on the discussion so far, following recommendations are put forward for consideration.

- Native and Non-Native- There should not be any division among the teachers based on their linguistic orientation rather focus should be on the successful classroom teaching. Native and non-native both should be included in the teaching staff to maintain diversity and scope of crosschecking.

- Cultural Pluralism- English language encompasses wide-range of variety and each of them inculcated in local culture. English is the field of cultural pluralism and heterogeneity. Focusing on only one aspect (nativism) of English means ignoring other fundamental characteristics of a language. So, English language should be taken as a whole with all its diversities. TESOL workers should promote EIL (English as an International Language) pedagogy in which teaching and learning process are embedded on valuing expressions of others (Phan, 2009).

- Regional Verities- Instead of native speaker models, we should encourage the use of regional varieties of English. In Saudi context, the variety that comes naturally to the students should be their regional variety. However, we should maintain the standard of comprehensibility.

- Culturally Responsive Teaching- We need to promote culturally responsive teaching so that, students can come out of the racial stereotypes. Classroom is the microcosm of our society, and classroom cohesion is dependant in teacher's ability to draw on experiences of all the students in the classroom. Culturally responsive teaching avoids focusing on stereotypes like accent or dress, it keeps its focus on ways of communication. Above all, the emphasis should be on holistic or integrated learning (Gay, 2002:110).

- Emphasis on Contextual Teaching- There should be an awareness about context of teaching. We should come out of this belief that "context is less important and incidental, or to be taken for granted' (Bax, 2003: 281). Any teacher-training course should include the high level of awareness of contextual factors. Non-native ELT teachers should receive cultural knowledge by being self-motivated about the culture or through training courses. Other teaching approaches or methodologies should include this contextual aspect.

- Students' Voice in the Classroom- Instead of over dependence on teacher- 
talk, student-voice should be encouraged more and teachers can exploit their L1 to facilitate their L2 learning process. As Tang (1997) stated, the shared mother-tongue is a useful instructional tool.

\section{Conclusion}

With the heightened speed of globalization process, the ELT field is also changing rapidly. English is no longer a native speaker's property. Non-native teacher's voices are also being heard. As Lasagabaster \& Sierra (2005) affirmed 'The centre of gravity is likely to shift from the native to the non-native speaker of English as the native finds it difficult to maintain their position as representative of the tongue' (p. 2008). A more liberal view of Native Speakers is: "Because English is International, its ownership is shifted to whoever wishes to use it" (Holliday: 2005:13). Amid all these arguments and counter arguments, teachers (native or non-native) should never forget their students and teaching objectives. 'Language teaching would benefit by paying attention to the L2 user rather than concentrating primarily on the native speaker' (Vivian Cook, 1999:185). An ideal teacher should equip himself with pedagogical expertise along with contextual knowledge of the teaching circumstances. Native speaking teachers should learn about students' culture whereas non-native English Speaking Teachers should familiarize themselves with the L2 culture. None of them should consider student as just an object rather they should treat students as human born in and with culture and language and individualized thought-processes. Teachers should prepare students to take their places in the world which will be vastly different from the world they live in now (Allard and Santoro 2004).

\section{References}

Al-Asmari, A. M., \& Khan, M. (2014). World Englishes in the EFL Teaching in Saudi Arabia. Arab World English Journal, 5(1).

Alharbi, H. A. (2015). Improving Students' English Speaking Proficiency in Saudi Public Schools. International Journal of Instruction, 8(1), 105-116.

Allard, A., \& Santoro, N. (2004, January). Making sense of difference? Teaching identities in postmodern contexts. In AARE 2004: Doing the public good: positioning educational research; AARE 2004 International Education Research conference proceedings (pp. 1-20). Australian Association for Research in Education.

Al-Seghayer, K. (2005). Teaching English in the Kingdom of Saudi Arabia: Slowly but steadily changing. Teaching English to the world: History, curriculum, and practice, $125-134$.

Alhareth, Y. A., \& Dighrir, I. A. (2014). The Assessment Process of Pupils' Learning in Saudi education system: A Literature Review. American Journal of Educational

Arab News (2015). Retrieved from http:/ / www.arabnews.com/saudiarabia/news/697371

Ball, S. (1990) Introducing Monsieur Foucault, in S. Ball, ed., Foucault and Education: Disciplines and Knowledge, Routledge, London.

Bax, S. (2003). The end of CLT: A context approach to language teaching. ELT journal, 57(3), 278-287.

Blackledge, A., \& Pavlenko, A. (2001). Negotiation of identities in multilingual contexts. 
Bourdieu, P. (1991) Thompson, J. (ed.) Language and Symbolic Power, Cambridge: Polity Press.

Butler, Y. G. (2007). Factors associated with the notion that native speakers are the ideal language teachers: An examination of elementary school teachers in Japan. JALT journal, 29(1), 7.

Cameron, D. (2005). Verbal hygiene. Routledge.

Chomsky, N. (1965). Aspects of the theory of syntax. Cambridge, MA: MIT Press.

Cook, V. (1999). Going beyond the native speaker in language teaching. TESOL quarterly, 33(2), 185-209.

Davies, A. (1991). The native speaker in applied linguistics. Edinburgh: Edinburgh University Press.

Elyas, T. (2008). The attitude and the impact of the American English as a global language within the Saudi education system. Novitas-Royal, 2(1), 28-48.

Eslami, Z., Moody, S., \& Pashmforoosh, R. (2019). Educating Pre-Service Teachers about World Englishes: Instructional Activities and Teachers' Perceptions. TESLEJ, 22(4), n4.

Hoffman, E. (1989). Lost in translation: A life in a new language. New York: Dutton.

Holliday, A. (2006). The struggle to teach English as an international language. Oxford, England: Oxford University Press.

Holliday, A. (2015). Native-speakerism: Taking the concept forward and achieving cultural belief. In (En) Countering native-speakerism (pp. 11-25). Palgrave Macmillan, London. https://doi.org/10.1057/9781137463500_2

Gay, G. (2002). Preparing for culturally responsive teaching. Journal of teacher education, 53(2), 106-116.

Graves, K. (2008). The language curriculum: A social contextual perspective. Language Teaching, 41(02).

Hall, S. (1997). Representation \& the media. Northampton, MA: Media Education Foundation.

Higgins, C. (2003). "Ownership" of English in the Outer Circle: An Alternative to the NSNNS Dichotomy. Tesol Quarterly, 615-644.

Janks, H. (2004). The access paradox, English in Australia, Number 139, February 2004. Pages 33- 42. Adelaide: AATE/ALEA joint IFTE Issue.

Kachru, B. B. (1982). The bilingual's linguistic repertoire. In Issues in international bilingual education (pp. 25-52). Springer US.

Kachru, B. B. (1990). The alchemy of English: The spread, functions, and models of non-native Englishes. University of Illinois Press.

Kachru, B. B. (1992). Models for non-native Englishes. The other tongue: English across cultures, 2, 48-74.

Kirkpatrick, A. (2007). World Englishes paperback with audio CD: Implications for international communication and English language teaching. Cambridge University Press.

KKU data retrieved from http://flt.kku.edu.sa/en/flt_facultylisten

Kramsch, C. (1998). Language and culture. Oxford University Press.

Miller, J. (2003): Audible difference: ESL and social identity

Nunan, D. (2003). The impact of English as a global language on educational policies and practices in the Asia-Pacific region. TESOL quarterly, 37(4), 589-613.

Lasagabaster, D., \& Sierra, J. M. (2002). University students' perceptions of native and non-native speaker teachers of English. Language Awareness, 11(2), 132-142. 
Lippi-Green, R. (1994). Accent, standard language ideology, and discriminatory pretext in the courts. Language in society, 23(02), 163-198.

Macaulay's Minute on Indian education (1835). Retrieved from http://www.columbia.edu/itc/mealac/pritchett/00generallinks/macaulay/txt _minute_education_1835.html

Mahboob, A., \& Elyas, T. (2014). English in the kingdom of Saudi Arabia. World Englishes, 33(1), 128-142.

Matsuda, A. (2017). Preparing teachers to teach English as an international language. Bristol: Multilingual Matters.

Norton, B., \& De Costa, P. (2019). LANGUAGE TEACHER IDENTITIES IN TEACHER EDUCATION. Qualitative Research Topics in Language Teacher Education, 12.

Phan Le Ha (2009). English as an international language: international student and identity formation, Language and Intercultural Communication, 9:3, 201-214, doi:10.1080/14708470902748855

Phillipson, R. (1992). Linguistic Imperialism. Oxford: Oxford University Press.

PhiN 32/2005:1 retrieved from http:/ / web.fu-berlin.de/phin/phin32/p32t1.htm

Pienemann, M. (1985). Learnability and syllabus construction. Modelling and assessing second language acquisition, 23-75.

Prior, P. (2001). Voices in text, mind, and society: Sociohistoric accounts of discourse acquisition and use. Journal of second language writing, 10(1), 55-81.

Rabab'ah, G. (2002). Communication problems facing Arab learners of English. Journal of Language and Learning, 3(1), 180-197.

Roberts, C., \& Sarangi, S. (1995). 'But are they one of us?': Managing and evaluating identities in work-related contexts. Multilingua-Journal of Cross-Cultural and Interlanguage Communication, 14(4), 363-390.

Schumann, J. H. (1986). Research on the acculturation model for second language acquisition. Journal of multilingual \& multicultural development, 7(5), 379-392.

Spolsky, B. (1969). Attitudinal aspects of second language learning. Language learning, 19(3-4), 271-275.

Tang, C. (1997). The identity of the nonnative ESL teacher: On the power and status of nonnative ESL teachers. TESOL Quarterly 31(3), 577-580.

Trudgill, P., \& Hannah, J. (2017). International English: A guide to varieties of English around the world. Routledge

Wajid, M. A., \& Saleem, M. (2016). Conflict in communicative language teaching theory and practice: a study in Saudi Arabian context. International Journal of Language Learning and Applied Linguistics World (IJLLALW), Volume 12 (1), May 2016; 47-59.

Wright, S. (1997). Language as a contributing factor in conflicts between states and within states. Current Issues in Language \& Society, 4(3), 215-237.

Zaid, M. A. (1993). Comprehensive analysis of the current system of teaching English as a foreign language in the Saudi Arabian intermediate schools (Doctoral dissertation, University of Colorado). Retrieved from:

https://elibrary.ru/item.asp?id=5726465 